\title{
PERBEDAAN NILAI ARUS PUNCAK EKSPIRASI (APE) PADA WANITA USIA PRODUKTIF PENDERITA ASMA YANG MENGIKUTI LATIHAN ZUMBA DAN YOGA
}

\author{
Rahma Cempaka Putri ${ }^{1}$, I Dewa Ayu Inten Dwi Primayanti², Luh Made Indah Sri \\ Handari $^{2}$, I Putu Adiartha Griadhi ${ }^{2}$ \\ ${ }^{1}$ Program Studi Sarjana Kedokteran dan Profesi Dokter, Fakultas Kedokteran, Universitas \\ Udayana, Denpasar, Bali, Indonesia \\ ${ }^{2}$ Departemen Fisiologi, Fakultas Kedokteran, Universitas Udayana, Denpasar, Bali, \\ Indonesia
}

E-Mail: rahmaacp@gmail.com

\begin{abstract}
ABSTRAK
Pendahuluan: Asma merupakan penyakit saluran pernapasan dengan angka prevalensi tinggi di Indonesia dan Provinsi Bali menduduki urutan ke-enam dengan prevalensi asma tertinggi di Indonesia. Penderita asma dianjurkan untuk melakukan latihan fisik untuk meningkatkan kebugaran serta meringankan dan mengurangi frekuensi kekambuhan. Zumba dan Yoga merupakan jenis latihan fisik yang memberikan banyak manfaat terutama pada fungsi paru. Tujuan: Membuktikan adanya perbedaan nilai APE pada wanita usia produktif penderita asma yang mengikuti latihan Zumba dan Yoga. Metode: Penelitian ini merupakan penelitian observasional analitik dengan pendekatan potong lintang yang melibatkan 18 wanita usia produktif penderita asma derajat intermiten atau persisten ringan pada kelompok Zumba dan Yoga. Sampel dipilih dengan teknik purposive sampling yang dilakukan pada tujuh studio senam Zumba dan Yoga di Denpasar selama bulan Juni - Oktober 2019. Data diperoleh dengan lembar pengumpulan data dan pengukuran APE menggunakan Peak Flow Meter. Data dianalisis dengan uji Parametrik T-Tidak Berpasangan untuk membandingkan nilai APE pada wanita penderita asma yang mengikuti latihan Zumba dan Yoga. Hasil: Pada wanita usia produktif penderita asma yang mengikuti latihan Zumba memiliki rata-rata nilai APE sebesar 431,11 L/menit, sedangkan penderita asma yang mengikuti latihan Yoga 398,89 L/menit, dengan $p=0,04(p<0,05)$ yang menunjukkan bahwa terdapat perbedaan bermakna pada nilai APE wanita usia produktif penderita asma yang mengikuti latihan Zumba dan Yoga.
\end{abstract}

Kata Kunci: Asma, Arus Puncak Ekspirasi, Zumba, Yoga

\section{THE DIFFERENCES OF PEAK EXPIRATORY FLOW (PEF) IN PRODUCTIVE AGE WOMEN WITH ASTHMA WHO JOIN ZUMBA AND YOGA EXERCISE}

\begin{abstract}
Background: Asthma is a respiratory disease with a high prevalence in Indonesia and the Province of Bali ranks as the sixth Province with the highest prevalence of asthma in Indonesia. Asthma patients are encouraged to do physical exercise in order to improve fitness as well as to relieve and reduce the frequency of recurrence. Zumba and Yoga are types of physical exercise that
\end{abstract}


provide many benefits, especially in lung function. Objective: The aim of this study is to prove the differences in PEF value in productive age women with asthma who join Zumba and Yoga exercise. Methods: Observational analytic study was held with a cross-sectional approach involving 18 women of productive age with mild intermittent or persistent asthma in the Zumba and Yoga groups. Samples were selected using a purposive sampling technique carried out at seven Zumba and Yoga gymnastics studios in Denpasar during June - October 2019. Data were obtained with data collection sheets and PEF measurements using Peak Flow Meter. Data were analyzed with the Parametric T-Paired Test to compare PEF values in women with asthma who were following Zumba and Yoga exercises. Results: In productive age women with asthma who join Zumba exercise had an average PEF equal to $431.11 \mathrm{~L} / \mathrm{min}$, while asthma patients who took Yoga exercise was $398.89 \mathrm{~L} / \mathrm{min}$, and $\mathrm{p}=0.04(\mathrm{p}<0.05)$, this results showed a significant differences of PEF between productive age women with asthma who join Zumba and Yoga exercise.

Keywords: Asthma, Peak Expiration Flow, Zumba, Yoga

\section{PENDAHULUAN}

Asma merupakan penyakit saluran pernapasan yang ditandai dengan hipersensitivitas saluran napas dan pengeluaran lendir yang berlebihan. Hingga kini penyakit asma masih menjadi masalah kesehatan pada hampir semua negara di dunia termasuk Indonesia, di mana diperkirakan jumlah penderita asma meningkat hingga 400 juta pada tahun 2025. ${ }^{1}$ Pada tahun 2013 terdapat delapan belas propinsi di Indonesia dengan angka prevalensi asma melebihi angka nasional, dan Provinsi Bali menduduki urutan ke-enam dengan prevalensi asma tertinggi di Indonesia. ${ }^{1}$

Asma dapat ditegakkan berdasarkan anamnesis yang baik, pemeriksaan fisik dan penilaian fungsi paru. Penilaian fungsi paru yang dapat dilakukan salah satunya adalah penilaian Arus Puncak Ekspirasi (APE). APE merupakan aliran udara maksimum yang dicapai selama ekspirasi paksa maksimal setelah inspirasi paksa. Pengukuran APE bertujuan untuk menilai derajat obstruksi saluran napas secara objektif dan evaluasi terapi asma. Pengukuran APE dapat dilakukan dengan menggunakan spirometer (gold standard) dan Peak Flow Meter. Peak Flow Meter merupakan alat pengukuran APE alternatif yang mudah digunakan, portable, dan harganya terjangkau. ${ }^{2}$

Penderita asma dahulu dilarang untuk melakukan latihan fisik karena dianggap dapat menyebabkan serangan asma (Exercise
Induce Asthma), namun kini penderita asma dianjurkan untuk melakukan latihan fisik dengan tujuan meningkatkan kebugaran dan daya tubuh, mengurangi dosis obat yang digunakan serta meringankan dan mengurangi frekuensi kekambuhan. ${ }^{3}$ Dengan latihan fisik teratur dengan dosis dan intensitas yang tepat dan adekuat, latihan fisik dapat memberikan manfaat fisiologis pada penderita asma terutama pada fungsi paru, toleransi dan tingkat ambang asma. ${ }^{3}$ Latihan fisik dapat merangsang pernapasan dan meningkatkan volume paru karena latihan fisik menyebabkan peningkatan kekuatan otot pernapasan. ${ }^{4}$

Terdapat berbagai jenis latihan fisik yang dikenal di masyarakat seperti bersepeda, berenang, senam aerobik dan lainnya, termasuk latihan Zumba dan Yoga. Zumba dan Yoga merupakan latihan yang menyenangkan, dengan risiko merugikan minimal dan harganya relatif terjangkau oleh karena itu ke dua jenis latihan ini digemari di seluruh dunia terutama pada kaum wanita. ${ }^{5,6}$ Latihan Zumba juga bermanfaat dalam menurunkan persentase lemak tubuh pada remaja putri. ${ }^{7}$ Menurut penelitian ilmiah, latihan Zumba rutin selama 2 minggu berpengaruh signifikan terhadap peningkatan VEP1 pada sampel yang mengikuti latihan Zumba, penelitian serupa juga menunjukkan terdapat perbedaan sangat bermakna pada parameter fungsi paru yaitu APE pada sampel yang melakukan latihan Zumba $\leq 8$ minggu dan $\geq 8$ minggu, di mana sampel yang berlatih 
$\geq 8$ minggu memiliki rerata APE yang lebih tinggi. ${ }^{4}$

Latihan Yoga merupakan metode latihan kebugaran dengan fokus pada pengaturan pernapasan dan relaksasi tubuh. Menurut penelitian yang memberikan intervensi Yogra Pranayama sebanyak 2 minggu sekali dengan durasi latihan 45 menit, terdapat peningkatan APE yang signifikan pada sampel yang diberikan intervensi dibandingkan dengan kelompok kontrol. ${ }^{9}$ Penelitian lain yang dilakukan oleh Siddiqui \& Phatale pada tahun 2018 juga menjelaskan hasil yang serupa, yaitu latihan Yoga dengan teknik Savitri Pranayama selama 16 minggu pada 30 subjek berusia 18-28 tahun secara signifikan meningkatkan APE dibandingkan dengan kelompok kontrol yang tidak rutin melakukan latihan Yoga. ${ }^{10}$

\section{METODE PENELITIAN}

Desain penelitian ini merupakan observasional-analitik dengan pendekatan potong lintang. Penelitian ini melibatkan 18 wanita berusia 20-45 tahun yang merupakan penderita asma derajat intermiten atau persisten ringan yang mengikuti latihan Zumba dan Yoga di tujuh Studio Senam di Denpasar selama bulan Juni-Oktober, 2019. Sampel terbagi menjadi 2 kelompok yaitu Zumba dan Yoga, 9 sampel pada masing masing kelompok. Sampel dipilih secara purposive sampling. Tujuh Studio Senam tersebut adalah Athaya Studio Bali, Senam Bugar Citra, Hawa Gym, De Gym Renon, Yoga Sati Bali, Mahaloka House of Yoga, dan Kelompok Latihan Yoga di Lapangan Puputan Renon. Perolehan data dilakukan dengan pengisian lembar pengumpulan data, informed consent, dan pengukuran APE dengan Peak Flow Meter. Analisis data dilakukan secara univariat dan bivariat. Uji Parametrik T-Tidak Berpasangan dilakukan untuk menganalisis perbedaan nilai APE pada ke dua kelompok latihan.

\section{HASIL PENELITIAN}

\section{Karakteristik Subjek Penelitian}

Tabel 1.

\begin{tabular}{|c|c|c|c|}
\hline \multicolumn{4}{|c|}{ Karakteristik Sampel } \\
\hline Karakteristik & $\begin{array}{c}\text { Kelompok } \\
\text { Zumba }\end{array}$ & $\begin{array}{c}\text { Kelompok } \\
\text { Yoga }\end{array}$ & Nilai $p$ \\
\hline \multicolumn{4}{|l|}{ Usia (tahun) } \\
\hline Mean \pm SD & $34,00 \pm 6,78$ & $34,89 \pm 8,48$ & 0,834 \\
\hline \multicolumn{4}{|l|}{ Tinggi Badan (cm) } \\
\hline Mean \pm SD & $163,20 \pm 3,46$ & $158,56 \pm 5,94$ & 0,058 \\
\hline \multicolumn{4}{|l|}{ Berat Badan (kg) } \\
\hline Mean \pm SD & $56,11 \pm 4,73$ & $51,11 \pm 7,20$ & 0,117 \\
\hline \multicolumn{4}{|l|}{ IMT $\left(\mathrm{kg} / \mathrm{m}^{2}\right)$} \\
\hline Mean \pm SD & $21,13 \pm 1,54$ & $20,26 \pm 1,80$ & 0,226 \\
\hline \multicolumn{4}{|l|}{ PersentaseAPE (\%) } \\
\hline Mean \pm SD & $89,45 \pm 7,71$ & $83,51 \pm 5,33$ & 0,086 \\
\hline \multicolumn{4}{|l|}{ Variabilitas APE (\%) } \\
\hline \multicolumn{4}{|l|}{ Derajat Asma: } \\
\hline - Intermiten & $4,56 \pm 2,06$ & $5,61 \pm 3,25$ & 0,548 \\
\hline - Persisten Ringan & $22,28 \pm 2,98$ & $21,18 \pm 1,93$ & 0,609 \\
\hline \multicolumn{4}{|l|}{ Frekuensi } \\
\hline \multicolumn{4}{|l|}{ Latihan(/minggu) } \\
\hline Mean \pm SD & $2,22 \pm 0,67$ & $2,44 \pm 1,24$ & 0,170 \\
\hline \multicolumn{4}{|l|}{$\begin{array}{l}\text { Lama Latihan } \\
\text { (menit/minggu) }\end{array}$} \\
\hline Mean \pm SD & $136,67 \pm 33,91$ & $183,33 \pm 82,77$ & 0,416 \\
\hline
\end{tabular}

Tabel 1 di atas menunjukkan bahwa pada karakteristik sampel yang berupa usia, tinggi badan, berat badan IMT, persentase APE, frekuensi latihan dalam seminggu dan lama latihan dalam menit dalam seminggu memiliki nilai $\mathrm{p}>0,05$. Hal tersebut menjelaskan bahwa karakteristik sampel antar ke dua kelompok tidak signifikan berbeda. Perbedaan nilai APE pada ke dua kelompok tidak dipengaruhi oleh karakteristik sampel.

\section{Perbedaan Nilai APE Berdasarkan Kelompok Usia, Derajat Asma, dan Lama Latihan}

Tabel 2.

Perbedaan Nilai APE Berdasarkan Kelompok Usia, Derajat Asma, dan Lama Latihan Kelompok Usia

\begin{tabular}{lllccc}
\hline Usia & $\begin{array}{c}\text { Kelompok } \\
\text { Latihan }\end{array}$ & $\mathrm{N}(\%)$ & $\begin{array}{c}\text { Mean APE } \\
(\mathrm{L} / \mathrm{menit})\end{array}$ & $\mathrm{t}$ & Nilai p \\
\hline 20-30 & Zumba & $3(33,33)$ & $420,00 \pm 45,83$ & $-0,653$ & 0,535 \\
\hline $31-45$ & & $6(66,67)$ & $436,67 \pm 31,41$ & & \\
\hline 20-30 & Yoga & $3(33,33)$ & $396,67 \pm 35,12$ & $-0,172$ & 0,868 \\
\hline
\end{tabular}




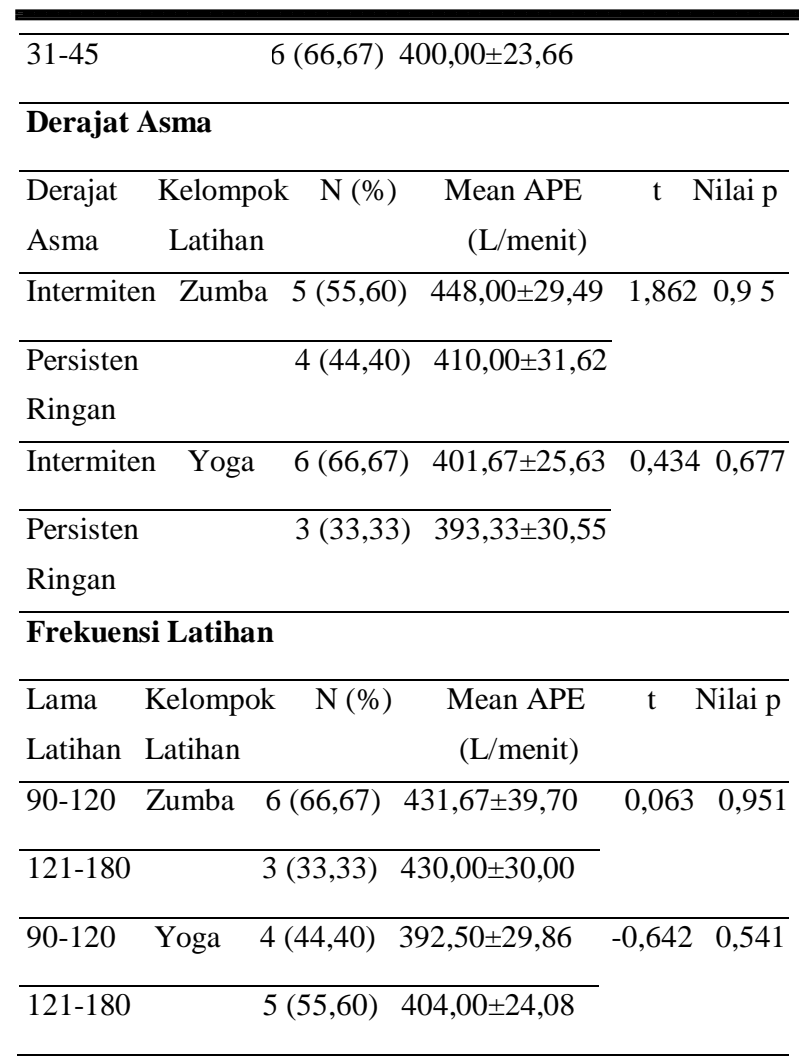

Berdasarkan Tabel 2 menunjukkan bahwa kelompok usia 20-30 tahun yang mengikuti latihan Zumba dan Yoga memiliki rerata nilai APE yang lebih rendah dibandingkan kelompok usia 31-45 tahun. Penderita asma derajat intermiten pada kelompok latihan Zumba dan Yoga memiliki rerata nilai APE yang lebih tinggi dibandingkan penderita asma derajat persisten ringan. Pada sampel yang berlatih Zumba 90120 menit dalam seminggu memiliki rerata nilai APE lebih tinggi dibandingkan sampel yang berlatih Zumba 121-180 menit dalam seminggu, namun hal sebaliknya terjadi pada kelompok latihan Yoga, Namun keseluruhan data memiliki nilai $\mathrm{p}>0,05$ yang menunjukkan ketiga karakteristik sampel tersebut yaitu kelompok usia, derajat asma, dan frekuensi latihan bukanlah faktor perbedaan nilai APE pada wanita usia produktif penderita asma yang mengikuti latihan Zumba dan Yoga.

\section{Uji Normalitas dan Homogenitas}

Tabel 3.

Uji Normalitas dan Homogenitas

Uji Normalitas* Uji

Kelompok

Kelompok

\begin{tabular}{ccc}
\hline Zumba & Yoga & \\
\hline Nilai $\mathrm{p}$ & Nilai $\mathrm{p}$ & Nilai $\mathrm{p}$ \\
\hline 0.708 & 0.577 & 0,735 \\
\hline
\end{tabular}

*Uji Normalitas dengan Saphiro Wilk test

**Uji Homogenitas dengan Levene's test

Berdasarkan Tabel 3, hasil uji normalitas dan uji homogenitas menunjukkan nilai $\mathrm{p}>0,05$ yang menunjukkan distribusi data masing - masing kelompok adalah normal. Uji homogenitas menunjukkan ke dua kelompok homogen dan dapat dibandingkan, sehingga uji hipotesis yang digunakan adalah uji parametrik T-Tidak Berpasangan.

\section{Perbedaan Nilai APE Pada Wanita Usia Produktif Penderita Asma yang Mengikuti Latihan Zumba dan Yoga}

Tabel 4.

Uji Parametrik T-Tidak Berpasangan

\begin{tabular}{lcccc}
\hline Kelompok & $\begin{array}{c}\text { Rerata APE } \\
\text { (L/menit) }\end{array}$ & $\begin{array}{c}\text { Perbedaan } \\
\text { Rerata }\end{array}$ & 95\% CI & Nilai p \\
\hline Zumba & $431,11 \pm 34,80$ & 32,22 & $1,64-62,79$ & 0,04 \\
Yoga & $398,89 \pm 25,71$ & 32,22 & $1,43-63,01$ & \\
\hline
\end{tabular}

Tabel 4 menunjukan bahwa nilai rerata APE kelompok latihan Zumba adalah 431,11 L/menit dengan standar deviasi 34,80, sedangkan pada kelompok latihan Yoga adalah 398,89 L/menit dengan standar deviasi 25,712. Rerata perbedaan APE pada ke dua kelompok tersebut adalah 32,322 L/menit dengan nilai signifikansi 0,04 . Dengan demikian diketahui bahwa $\mathrm{p}<0,05$ maka dapat disimpulkan terdapat perbedaan yang signifikan antara rata - rata APE kelompok Zumba dan rata - rata APE kelompok Yoga.

\section{PEMBAHASAN}

Nilai APE selain dipengaruhi oleh latihan fisik, juga dapat dipengaruhi oleh faktor lainnya di antaranya adalah usia, tinggi badan, berat badan, indeks massa tubuh, derajat asma, frekuensi latihan dan lama latihan dalam menit dalam satu minggu. Untuk mengetahui bahwa faktor yang mempengaruhi perbedaan nilai APE pada ke dua kelompok dalam penelitian ini adalah jenis latihan fisik (latihan Zumba atau latihan 
Yoga), maka faktor - faktor lain di atas didesain agar tidak mempengaruhi nilai APE dengan metode control by design yaitu melalui inklusi dan eksklusi yang telah ditetapkan serta dilakukan control by analysis. Faktor yang dilakukan control by design adalah tinggi badan, berat badan, IMT dan frekuensi latihan, sedangkan faktor yang dilakukan control by analysis adalah usia, derajat asma, persentase APE, variabilitas APE dan lama latihan dalam menit dalam satu minggu.

Berdasarkan hasil analisis data nilai APE penderita asma yang mengikuti Latihan Zumba dan Yoga dengan Uji Parametrik T Tidak Berpasangan ditemukan perbedaan yang bermakna di antara ke dua kelompok tersebut, di mana nilai APE penderita asma yang mengikuti Latihan Zumba lebih tinggi daripada nilai APE penderita asma yang mengikuti latihan Yoga. Hal ini sejalan dengan tipe latihan Zumba yang merupakan latihan dengan intensitas sedang yang dapat meningkatkan kebugaran paru, sedangkan latihan Yoga merupakan latihan dengan intensitas ringan yang memusatkan pada pernapasan.

Pada peserta yang mengikuti latihan Zumba, dalam satu sesi dibagi menjadi beberapa bagian. Pertama melakukan pemanasan atau peregangan otot - otot kepala, tangan dan kaki, dengan diiringi lagu berirama. Pemanasan ini dilakukan dalam waktu 15 menit pertama, kemudian dilanjutkan dengan peningkatan intensitas hingga sedang lalu berat selama 45 menit, dan diakhiri dengan pendinginan dengan intensitas yang dikurangi selama 15 menit. Sedangkan pada Kelompok Latihan Yoga terdiri dari pemanasan yang merupakan peregangan otot - otot selama 15 menit, kemudian dilanjutkan dengan asana (postur fisik) dan pengaturan pernapasan (pranayama) selama 60 menit lalu diakhiri dengan meditasi selama 5-15 menit.

Hasil penelitian ini didukung dengan penelitian observasional yang dilakukan pada wanita berusia 18-24 tahun bahwa latihan rutin Zumba sangat signifikan berhubungan dengan nilai APE $(r=0,806 ; p=0,000)$, subjek yang latihan rutin Zumba selama $\geq 8$ minggu memiliki rerata nilai APE yang lebih tinggi dibandingkan subjek yang mengikuti latihan rutin Zumba $<8$ minggu. $^{8}$ Penelitian oleh Suwongso dkk. (2016) juga mengungkapkan hasil yang sejalan yaitu dengan intervensi latihan Zumba selama 2 minggu pada 20 subjek berusia 16-19 tahun, menunjukkan peningkatan $\mathrm{VEP}_{1}$ yang signifikan pada subjek $(p=0,00){ }^{11}$

Latihan Zumba merupakan jenis latihan dengan intensitas sedang hingga berat yang sesuai dengan rekomendasi latihan fisik untuk pasien asma, yaitu latihan yang didahului pemanasan dengan intensitas yang cukup dan diakhiri dengan pendinginan hingga penurunan denyut jantung 20x/menit lebih rendah dari awal latihan, serta latihan Zumba merupakan latihan aerobik yang mencapai intensitas 50-85\% $\mathrm{VO}_{2}$ max. ${ }^{3}$ Latihan Zumba dapat meningkatkan kekuatan otot pernapasan dan efisiensi otot pernapasan yang dapat mempengaruhi ekspansi otot rongga dada, yaitu semakin kuat otot dada, semakin besar volume rongga dada dan kapasitas udara masuk meningkat. ${ }^{12}$

Rangkaian pada latihan Zumba juga serupa dengan rangkaian pada senam asma yang dianjurkan oleh Yayasan Asma Indonesia sebagai latihan fisik yang aman dan bermanfaat pada penderita asma (Fitriani, 2009). Di mana senam asma terdiri dari pemanasan, latihan inti A dan inti B irama 120-130/menit, serta diikuti aerobik dan pendinginan. ${ }^{13}$ Pemanasan, aerobik dan pendinginan merupakan bagian latihan pada senam asma yang serupa dengan Zumba, namun latihan Zumba dikemas berbeda yaitu diiringi lagu latin dan intensitas gerakan lebih tinggi serta durasi aerobik lebih lama dibandingkan dengan senam asma.

Sedangkan latihan Yoga merupakan jenis latihan intensitas ringan yang memfokuskan pada postur tubuh dan latihan pernapasan. Latihan Yoga sesuai dengan rekomendasi latihan untuk penderita asma, yaitu latihan yang didahului dengan pemanasan dengan intensitas cukup dan diakhiri dengan pendinginan serta latihan dengan frekuensi 3-4 kali/minggu. ${ }^{3}$ Namun 
latihan Yoga bukanlah jenis latihan aerobik karena tidak mencapai intensitas 50-85\% $\mathrm{VO}_{2}$ max, pada latihan Yoga memfokuskan pada latihan pernapasan, postur tubuh dan relaksasi. Hal inilah yang menyebabkan nilai APE pada kelompok latihan Yoga lebih rendah dibandingkan nilai APE pada kelompok latihan Yoga.

Adapun latihan Yoga dapat mempengaruhi pernapasan dengan mekanisme penurunan ritme basal bulbopontine kompleks, sehingga tebentuk pola penapasan baru yang panjang pada fase inspirasi dan ekspirasi serta peregangan otot paru mencapai kapasitas maksimalnya. Gerakan pada Yoga meningkatkan inflasi paru yang akan menstimulasi pelepasan surfaktan paru sehingga meningkatkan compliance paru, serta Yoga memberikan efek ketenangan sehinga mengurangi efek bronkostriktor. ${ }^{14}$

\section{KETERBATASAN PENELITIAN}

1. Pada penelitinian ini, peneliti tidak mengkontrol riwayat lama berlatih Zumba dan latihan Yoga pada subjek penelitian, yang dapat mempengaruhi peningkatan APE pada subjek penelitian. Penelitian selanjutnya diharapkan untuk mengontrol variabel ini untuk mendapatkan hasil yang lebih akurat.

2. Peneliti tidak memantau kepatuhan subjek penelitian dalam melakukan setiap gerakan pada latihan Zumba dan Yoga, yang dapat mempengaruhi nilai APE.

3. Penelitian ini menganalisis dua kelompok dengan metode observasional dan pengukuran parameter fungsi paru yang dilakukan hanya APE. Perlu dilakukan penelitian selanjutnya dengan metode eksperimental pada kelompok latihan Zumba, Yoga atau ke duanya dengan metode time series, serta pengukuran fungsi paru menggunakan parameter yang lebih akurat dan spirometer.

\section{SIMPULAN}

Pada penelitian yang dilaksanakan pada tujuh Studio Senam Zumba dan Yoga di Denpasar pada 18 sampel selama bulan JuniOktober 2019, ditemukan perbedaan bermakna antara nilai APE pada wanita usia produktif penderita Asma yang mengikuti latihan Zumba dan latihan Yoga. Nilai APE wanita usia produktif penderita asma yang mengikuti latihan Zumba lebih tinggi dibandingkan yang mengikuti latihan Yoga.

\section{DAFTAR PUSTAKA}

1. Balitbang Kemenkes RI. 2013. Riset Kesehatan RISKESDAS. Jakarta: Balitbang Kemenkes RI.

2. Lasmana, P. D. 2010. Perbedaan Nilai Arus Puncak Ekspirasi Antara Polisi Satlantas dengan Polisi Bagian Administrasi. Surakarta: Universitas Sebelas Maret.

3. Wijaya, I.M. 2015. Aktivitas Fisik (Olahraga) Pada Penderita Asma. Jurnal Pendidikan Jasmani Kesehatan dan Rekreasi. Online. Tersedia di: https://ejournal.undiksha.ac.id/index.php/ semnasmipa/article/view/10301 (diunduh: 25 Januari 2018).

4. Jayanti, U., Rumampuk, J.F., Supit, W. 2014. Pengaruh Latihan Zumba Terhadap Nilai FEV1. Manado: Universitas Sam Ratu langi.

5. Luettgen, M., Foster, C., Doberstein, S., dkk. 2012. Zumba®: Is the "Fitness Party" a Good Workout? Journal of Sports Science \& Medicine, 11(2): 357358.

6. Govindaraj, R., Karmani, S., Varambally, S. 2016. Yoga and physical exercise - a review and comparison. International Review of Psychiatry, 28(3): 242-253.

7. Ikayani, N, P., Juhanna, I, V., Primayanti, I.D.A.I.D. Zumba Can Decrease Body Fat Percentage in Overweight Adolescent Girls in Denpasar City. Majalah Ilmiah Fisioterapi Indonesia, 7(3): 41-44. 
8. Azhari, A., Sumekar, T. A., Hardian. Pengaruh Latihan Zumba Terhadap Arus Puncak Ekspirasi Pada Wanita Usia Muda. Media Medika Muda. Online. 4(4): 642-648. Tersedia di: http://ejournals1.undip.ac.id/index.php/medico

9. Putra, M.M. 2017. Yoga Pranayama Increases Peak Expiratory Flow (PEF) in Patient with Asthma. Advances in Health Sciences Research, 3: 207-210. Tersedia di: https://doi.org/10.2991/inc-17.2017.4 (diakses: 25 Januari 2019).

10. Siddiqui, S.M., \& Phatale, R.S. 2018. To Study the Effect of Savitri Pranayama Practice on Peak Expiratory on Peak Expiratory Flow Rate. Online. 8(3): 4546. Tersedia di: https://wwjournals.com/index.php/ijar/art icle/view/2609/0 (diakses: 27 September 2018).

11. Suwongso, H.L., Rumampuk, J.F., Danes, V.R. 2016. Hubungan Antara Senam Zumba Terhadap Nilai FEV1 Pada Mahasiswa Semester 1 Fakultas Kedokteran Universitas Sam Ratulangi Manado. Journal e-Biomedik. 4(1): 30.

12. Hall \& John, E. 2016. Guyton and Hall Textbook of Medical Physiology $13^{\text {th }}$ edition. Philadelphia: Elsevier.

13. Fitriani, U. 2009. Perbedaan Nilai APE (Arus Puncak Ekspirasi) Pada Penderita Asma yang Mengikuti Senam Asma dan Tidak Mengikuti Senam Asma. Surakarta: Universitas Sebelas Maret.

14. Prakash, C.A. \& Viswanatha. 2016. Effects of pranayama on respiratory parameters among healthy athlete boys. International Journal of Physical Education, Sports and Health. Online. 3(2): 184-185. Tersedia di: http://www.kheljournal.com/archives/201 6/vol3issue2/PartD/3-2-43.pdf (diakses: 7 Oktober 2018). 